\title{
Economic evaluation of bevacizumab in the treatment of non-small cell lung cancer (NSCLC)
}

This article was published in the following Dove Press journal:

ClinicoEconomics and Outcomes Research

25 July 2012

Number of times this article has been viewed

\author{
Chun-Ru Chien ${ }^{1,2}$ \\ Ya-Chen Tina Shih ${ }^{3}$ \\ 'Department of Radiation Oncology, \\ China Medical University Hospital, \\ Taichung, Taiwan; ${ }^{2}$ School of Medicine, \\ College of Medicine, China Medical \\ University, Taichung, Taiwan; ${ }^{3}$ Section \\ of Hospital Medicine, Department \\ of Medicine, University of Chicago, \\ Chicago, IL, USA
}

Background: Delivering affordable cancer care is becoming increasingly important. Bevacizumab (BEV) is a costly molecular targeted agent effective for a variety of cancer including lung cancer. The objective of this review is to assess published economic evaluation of BEV in the treatment of non-small cell lung cancer (NSCLC).

Methods: A literature search in PubMed, Cochrane, and the Health Technology Assessment reports for English-language publications before February 2012 was performed. Studies were independently screened by two reviewers, and eight publications were included in the review. The results of these eight articles were tabulated and all cost estimates were reported in 2011 US dollars.

Results: Among the eight articles, three were cost studies and five were cost-effectiveness/ utility analysis. For first-line treatment, BEV-containing regimen was reported to be the most costly regimen in one study but cost saving when compared with pemetrexed/cisplatin in another study. When compared with other regimens, BEV-containing regimen was reported to be cost effective in two cost-effectiveness studies (incremental cost-effectiveness ratio [ICER] in the range of US\$30,318-US\$54,317 per life year) but not cost effective in the other three studies (ICER over US\$300,000 per life year).

Conclusion: In this review of economic evaluation of BEV in the treatment of NSCLC, it was found that the literature was not conclusive on the economic benefit of BEV. The role of BEV in other treatment settings for NSCLC was unknown. Further studies, such as clinical trials with adequate power to compare the efficacy between low dose and high dose BEV, potential impact of predictive biomarkers for $\mathrm{BEV}$, and comprehensive economic evaluation will strengthen the current state of knowledge on the economic value of BEV in NSCLC.

Keywords: health economic evaluation, cancer care, cost effectiveness

\section{Introduction}

The high costs associated with emerging oncology products have led to a faster pace of growth in the costs of cancer compared with other diseases. Delivering affordable cancer care is a growing concern globally, as is highlighted in a recent paper. ${ }^{1}$ Non-small cell lung cancer (NSCLC) is the leading cause of cancer death worldwide. Although recent advances in medical technologies and pharmaceutical innovations have improved the outcome of patients with NSCLC, the cost-effectiveness of some emerging treatments for NSCLC, such as bevacizumab (BEV), remains inconclusive..$^{2-4}$

BEV (Hoffmann-La Roche Ltd, Avastin, Basel, Switzerland), a molecular targeted agent in a class of drugs known as monoclonal antibodies, is one of the major advances in recent treatment of NSCLC. ${ }^{5}$ BEV was first approved by the Food and
Correspondence: Ya-Chen Tina Shih Department of Medicine, University of Chicago, 584I South Maryland Avenue, MC 5000, Chicago, IL 60637, USA

Tel +l 7737020406

Fax +l 7737957398

Email tinashih@uchicago.edu 
Table I Cost analysis for BEV in the treatment of NSCLC

\begin{tabular}{|c|c|c|c|c|c|}
\hline $\begin{array}{l}\text { Authorl } \\
\text { country }\end{array}$ & Approach & $\begin{array}{l}\text { Cost type and } \\
\text { study perspective }\end{array}$ & $\begin{array}{l}\text { Time frame } \\
\text { and reference } \\
\text { year for cost }\end{array}$ & Data sources & Study population \\
\hline $\begin{array}{l}\text { Isla et } \mathrm{al}^{\mathrm{b}, 12} \\
\text { Europe } \\
\text { (Spain) }\end{array}$ & $\begin{array}{l}\text { Simple calculation: } \\
\text { (quantity of use) } \times \\
\text { (unit cost) }\end{array}$ & $\begin{array}{l}\text { Direct medical cost; } \\
\text { Payer (Spanish } \\
\text { national health } \\
\text { care system) }\end{array}$ & $\begin{array}{l}\text { A complete course } \\
\text { of treatment } \\
\text { (eg, first-line, BSC); } \\
2009 €\end{array}$ & $\begin{array}{l}\text { Unit cost: from Spanish } \\
\text { Health Costs Database } \\
\text { eSalud and Spanish } \\
\text { Database of Medicine; } \\
\text { Health Utilization: } \\
\text { Delphi panel }\end{array}$ & $\begin{array}{l}\text { - Patients with } \\
\text { advanced or } \\
\text { metastatic NSCLCc } \\
\text { - Average } \\
\text { weight } 70 \mathrm{~kg}\end{array}$ \\
\hline $\begin{array}{l}\text { Bischoff et ald }{ }^{\mathrm{d}, 13} \\
\text { Europe } \\
\text { (Italy and } \\
\text { Germany) }\end{array}$ & $\begin{array}{l}\text { Simple calculation: } \\
\text { (quantity of use) } \times \\
\text { (unit cost) }\end{array}$ & $\begin{array}{l}\text { Direct medical cost; } \\
\text { Payer (national } \\
\text { health service) }\end{array}$ & $\begin{array}{l}\text { Monthly cost } \\
2009 €\end{array}$ & $\begin{array}{l}\text { Dosage and administration: } \\
\text { literatures; } \\
\text { Unit cost: Italian Medicines } \\
\text { Agency, Official Pharmacists } \\
\text { Price Schedule in } \\
\text { Germany }\end{array}$ & $\begin{array}{l}\text { - Patients with } \\
\text { advanced non } \\
\text { squamous NSCLC } \\
\text { - Average weight } \\
71 \mathrm{~kg}, \\
\text { BSA I.8 (Italy) or } \\
\text { I.9 (Germany) }\end{array}$ \\
\hline $\begin{array}{l}\text { Stanisic et } \mathrm{al}^{\mathrm{d}, 14} \\
\text { Europe } \\
\text { (France, } \\
\text { Germany, } \\
\text { Italy, and Spain) }\end{array}$ & $\begin{array}{l}\text { Simple calculation: } \\
\text { (number of } \\
\text { nonworking days) } \times \\
\text { (labor cost) }\end{array}$ & $\begin{array}{l}\text { Indirect costs } \\
\text { (productivity loss); } \\
\text { Societal }\end{array}$ & $\begin{array}{l}\text { I and I.5 year; } \\
2009 €\end{array}$ & $\begin{array}{l}\text { - PFS: Phase } 3 \text { trials } \\
\text { - Return to work: } \\
\text { epidemiological and } \\
\text { experts' opinion } \\
\text { - Labor costs: EUROSTAT }\end{array}$ & $\begin{array}{l}\text { Patients with } \\
\text { nonsquamous mNSCLC, } \\
\text { PS 0-I, age }<55 \text { years }\end{array}$ \\
\hline
\end{tabular}

Drug Administration (FDA) for the treatment of metastatic colorectal cancer in 2004 in the United States. The FDA approval was extended to first-line treatment in combination with chemotherapy for common types of metastatic NSCLC in 2006, and then further extended to second-line treatment of glioblastoma and metastatic renal cell cancer.

In a randomized Phase 3 study, Sandler et al reported that $\mathrm{BEV}$ in combination with chemotherapy was associated with a hazard ratio (of death) of $0.79(P=0.003)$ when compared with chemotherapy alone. ${ }^{6}$ The dosage of BEV approved by the FDA for the treatment of non-squamous, unresectable, locally advanced, recurrent or metastatic NSCLC is $15 \mathrm{mg} / \mathrm{kg}$, administered intravenously every 3 weeks in combination with carboplatin and paclitaxel. ${ }^{7}$ Although the efficacy of BEV has been demonstrated in clinical trials, costs associated with $\mathrm{BEV}$ raise a major concern regarding the affordability of this novel agent among clinicians and payers, as well as patients. Drug cost alone for BEV-containing regimens is about twice as high as that for regimens without BEV among patients with metastatic colorectal cancer. ${ }^{8}$ Another study estimated that the initial treatment cost per person for BEV-containing regimens in metastatic colorectal cancer is around US\$80,000. ${ }^{9}$ While the costs and cost-effectiveness of BEV in the treatment of metastatic colorectal cancer have been explored in numerous studies, less is known about the economics of BEV in NSCLC. The objective of this study was to provide a critical review of economic evaluation of BEV in the treatment of NSCLC.

\section{Methods}

A literature search in PubMed ${ }^{\circledR}$, Cochrane, and the Health Technology Assessment (HTA) reports published by the National Institute for Health Research HTA Programme in the United Kingdom for peer-reviewed English-language articles published prior to February 2012 was performed using the following search terms: "([Bevacizumab] OR [Avastin]) AND ([non-small cell lung cancer] OR [NSCLC]) AND ([cost] OR [econ*] OR [burden] OR [finan*])", where * represents a wildcard. The titles and abstracts of articles identified in the search were independently reviewed by both authors. Further reviews of full-text articles and manual searches of the bibliography in the articles identified above led to the final selection of eight publications in the study. These eight studies were then classified into two categories: cost analysis and cost-effectiveness/cost-utility analysis (CEA/CUA).

Tables 1 and 2 summarize the study characteristics and key findings of studies in the cost analysis and CEA/CUA 


\begin{tabular}{|c|c|c|c|}
\hline $\begin{array}{l}\text { Setting, BEV dosing, } \\
\text { and intervention }\end{array}$ & Results $^{\mathbf{a}}$ & Conclusion & Comment and sensitivity analyses \\
\hline $\begin{array}{l}\text { First-line BEV dose: } \\
7.5-15 \mathrm{mg} / \mathrm{kg}\end{array}$ & $\begin{array}{l}\text { First-line } B C P \text { mean } \\
\text { total cost }=\$ 29,897 \\
\text { First-line } P C \text { mean } \\
\text { total cost }=\$ 19,678 \\
\text { Other first-line } \\
\text { regimens }<\$ 13,000\end{array}$ & $\begin{array}{l}\text { The cost of more recently } \\
\text { approved targeted anticancer } \\
\text { treatments (eg, BEV, PEM) } \\
\text { is higher than that of older } \\
\text { anticancer pharmacotherapies }\end{array}$ & $\begin{array}{l}\text { - Study objective: to describe treatment } \\
\text { patterns and costs associated with treating } \\
\text { advanced or metastatic NSCLC in Spain } \\
\text { - Mean total cost included pharmacological, } \\
\text { administration, adverse event, and follow-up } \\
\text { - Sensitivity analysis only dealt with } \\
\text { uncertainty in resource utilization }\end{array}$ \\
\hline $\begin{array}{l}\text { First-line BEV dose } \\
(7.5 \mathrm{mg} / \mathrm{kg}) \text {, two comparisons: } \\
\text { - BEV versus PEM } \\
\text { - BCG versus PC }\end{array}$ & $\begin{array}{l}\text { Monthly cost-saving: } \\
\text { - } \$ \text { PEM - } \$ B E V: \text { I I,783 } \\
\text { (Italy), } \$ 3,159 \text { (Germany) } \\
\text { - } \$ P C-\$ B C G ~ \$ I, I 82 \\
\text { (Italy), } \$ 549 \text { (Germany) }\end{array}$ & $\begin{array}{l}\text { From a budget perspective, } \\
\text { BEV should be considered } \\
\text { as a preferred targeted } \\
\text { treatment of choice } \\
\text { for advanced nonsquamous } \\
\text { NSCLC }\end{array}$ & $\begin{array}{l}\text { - One-way sensitivity analysis suggested } \\
\text { results were robust, but the analysis } \\
\text { varied patient weight, and the cost } \\
\text { of gemcitabine and administration } \\
\text { - Costs included drug acquisition and } \\
\text { treatment administration, but did not } \\
\text { consider costs of toxicities }\end{array}$ \\
\hline $\begin{array}{l}\text { First-line BEV dose: } 7.5 \mathrm{mg} / \mathrm{kg} \\
\text { in one trial and } 15 \mathrm{mg} / \mathrm{kg} \text { in } \\
\text { another trial; } B C G \text { versus } \\
C G \text { or } B C P \text { versus } C P\end{array}$ & $\begin{array}{l}\text { Mean cost saving per PF } \\
\text { patient returned to } \\
\text { work at year I: } \\
\text { France: } \$ 24,63 \text { I } \\
\text { Germany: } \$ 26,082 \\
\text { Italy: } \$ 20,765 \\
\text { Spain: } \$ 16,702\end{array}$ & $\begin{array}{l}\text { Longer PFS associated } \\
\text { with BEV-based treatment } \\
\text { can result in substantial } \\
\text { cost savings in PF patients } \\
\text { with mNSCLC }\end{array}$ & $\begin{array}{l}\text { - Sensitivity analyses were performed } \\
\text { for employment patterns and labor } \\
\text { costs, magnitude of cost savings was } \\
\text { sensitive to these parameters } \\
\text { - Reported estimates were conditional means } \\
\text { (ie, conditioning on patients who were eligible } \\
\text { to return to work), not the average cost saving }\end{array}$ \\
\hline
\end{tabular}

Notes: aDollars in 2011 USD; bsponsored by a pharmacy company that does not produce either bevacizumab or pemetrexed; climited to patients with nonsquamous histology for regimens containing BEV or PEM; ' dsponsored by a pharmacy company that does produce Bevacizumab.

Abbreviations: BCG, BEV + cisplatin + gemcitabine (CG); BCP, BEV + carboplatin + paclitaxel (CP); BEV, bevacizumab; BSA, body surface area; BSC, best supportive care; $\mathrm{CP}$, carboplatin/paclitaxel; mNSCLC, metastatic non-small cell lung cancer; NSCLC, non-small cell lung cancer; PC, PEM + cisplatin; PEM, pemetrexed; PF, progression free; PFS, progression-free survival; PS, performance status.

category, respectively. All cost estimates are reported in 2011 USD. For studies reporting costs in USD, the estimates were normalized to 2011 dollars using the medical care services component of the consumer price index if costs in that study were not already reported in 2011 USD. ${ }^{10}$ For studies reporting costs as currency in other currencies, the estimates were converted to 2011 USD by first applying the local consumer price index to normalize the costs to 2011 and then using the purchasing power parity index to convert the local currency to USD. ${ }^{11}$ For studies that did not specify the year of cost reporting, the authors assumed the year of publication to be the reference year of cost reporting.

\section{Results}

Figure 1 depicts the flow chart of the literature search process. As mentioned earlier, the search identified eight publications that examined various economic aspects of BEV in the treatment of NSCLC, including three cost studies ${ }^{12-14}$ and five publications of CEA/CUA. ${ }^{15-19}$

\section{Cost analysis}

Table 1 lists the characteristics of the three cost studies that estimated the costs of BEV in the first-line treatment of non-squamous metastatic or advanced NSCLC. All were European studies; two studies reported direct medical costs, and one reported indirect costs. Costs in all three studies were calculated as the sum of the product of the quantity of resource utilization and its associated unit cost across various items of resources.

The two studies reporting direct medical costs reached different conclusions regarding whether BEV-containing regimen was cost saving when compared with the new third-generation chemotherapy that contains pemetrexed (PEM). A closer examination of these two studies indicates that they differed in many ways, from sponsorship and the country or countries of the study, to elements included in the calculation of direct medical costs. The comparison between BEV- and PEM-containing regimens in Isla et $\mathrm{al}^{12}$ was based on a treatment patterns study that included many first- and second-line chemotherapy regimens, as well as best supportive care, for NSCLC patients with different performance status, whereas Bischoff et $\mathrm{al}^{13}$ focused only on two regimens in their comparisons: $\mathrm{BEV}$ in combination with cisplatin and gemcitabine (BCG) versus PEM plus cisplatin (PC). Both studies compared BEV-containing regimens with $\mathrm{PC}$; in one study, the mean cost of chemotherapy involving 
Table 2 Cost-effectiveness/utility analysis of BEV in the treatment of NSCLC

\begin{tabular}{|c|c|c|c|c|c|}
\hline $\begin{array}{l}\text { Authorl } \\
\text { country }\end{array}$ & Approach & $\begin{array}{l}\text { Cost type and } \\
\text { study perspective }\end{array}$ & $\begin{array}{l}\text { Time frame } \\
\text { and reference } \\
\text { year for cost }\end{array}$ & Data sources & Study population \\
\hline $\begin{array}{l}\text { Klein et } a^{\mathrm{b}, 15} \\
\text { USA }\end{array}$ & $\begin{array}{l}\text { Modeling, } \\
\text { semi-Markov } \\
\text { model, no } \\
\text { discounting }\end{array}$ & $\begin{array}{l}\text { - Direct medical cost } \\
\text { - US payer's } \\
\text { perspective }\end{array}$ & $\begin{array}{l}\text { - } 2 \text { year } \\
\text { - } 2009 \text { USD } \\
\text { (assumed) }\end{array}$ & $\begin{array}{l}\text { - Clinical parameters: RCT } \\
\text { - Utility: literature } \\
\text { - Cost: medicare } \\
\text { reimbursement rate } \\
\text { and analysis of claim } \\
\text { database (PharMetrics) }\end{array}$ & $\begin{array}{l}\text { Advanced NSCLC, } \\
\text { either nonsquamous } \\
\text { or all histology }\end{array}$ \\
\hline $\begin{array}{l}\text { Giuliani et al }\left.\right|^{c, 16} \\
\text { Italy }\end{array}$ & $\begin{array}{l}\text { Modeling } \\
\text { Markov model, } \\
\text { costs and } \\
\text { outcomes } \\
\text { discounted at 3.5\% }\end{array}$ & $\begin{array}{l}\text { - Direct medical costs } \\
\text { - Italian health } \\
\text { care payer's }\end{array}$ & $\begin{array}{l}\text { - } 5 \text { year } \\
\text { - } 2009 €\end{array}$ & $\begin{array}{l}\text { - Clinical parameters: RCT } \\
\text { - Cost: literature, Italian } \\
\text { negotiated price, and } \\
\text { assumption }\end{array}$ & $\begin{array}{l}\text { Advanced nonsquamous } \\
\text { NSCLC; BW 7I kg, } \\
\text { BSA } 1.8 \mathrm{~m}^{2}\end{array}$ \\
\hline Goulart and & Modeling & - Direct medical cost & - 4 years & - Clinical parameters: RCT & Advanced nonsquamous \\
\hline Ramsey USA & $\begin{array}{l}\text { Markov model, } \\
\text { costs and } \\
\text { outcomes } \\
\text { discounted at } 3 \%\end{array}$ & $\begin{array}{l}\text { - US payer's } \\
\text { perspective }\end{array}$ & - 2010 USD & $\begin{array}{l}\text { - Utility: literature } \\
\text { - Cost: ASP, Medicare fee } \\
\text { schedule, and analysis of } \\
\text { claim database (SEER- } \\
\text { Medicare) }\end{array}$ & NSCLC, ECOG PS 0 or I \\
\hline Ahn et $\mathrm{a}^{\mathrm{l}, 18}$ & Modeling, & - Direct medical cost & - Lifetime & - Clinical parameters: RCT & Advanced nonsquamous \\
\hline $\begin{array}{l}\text { Asia (Korea } \\
\text { and Taiwan) }\end{array}$ & $\begin{array}{l}\text { Markov model, } \\
\text { cost and outcome } \\
\text { discounted at } 5 \% \\
\text { (Korea) and 3\% } \\
\text { (Taiwan) }\end{array}$ & - Payer's perspective & - 2011 USD & $\begin{array}{l}\text { Cost: BSC and AE costs } \\
\text { from literature, and } \\
\text { government-published } \\
\text { fee schedules }\end{array}$ & $\begin{array}{l}\text { NSCLC, BW } 56.9 \text { kg (Korea), } \\
60 \mathrm{~kg} \text { (Taiwan), BSA } 1.62 \mathrm{~m}^{2}\end{array}$ \\
\hline $\begin{array}{l}\text { Klein et } a^{b, 19} \\
\text { USA }\end{array}$ & $\begin{array}{l}\text { Modeling } \\
\text { Semi-Markov, } \\
\text { cost and outcome } \\
\text { discounted at } 3 \%\end{array}$ & $\begin{array}{l}\text { - Direct medical cost } \\
\text { - US payer's } \\
\text { perspective }\end{array}$ & $\begin{array}{l}\text { - Three years } \\
\text { - } 2009 \text { USD }\end{array}$ & $\begin{array}{l}\text { - Clinical parameters: RCT } \\
\text { - Cost: Medicare } \\
\text { reimbursement rate and } \\
\text { analysis of claim database } \\
\text { (PharMetrics) }\end{array}$ & $\begin{array}{l}\text { Advanced NSCLC patients } \\
\text { who have completed first-line } \\
\text { platinum double chemotherapy } \\
\text { without progression }\end{array}$ \\
\hline
\end{tabular}

BEV was US $\$ 10,000$ higher than that of PC, whereas in the other study BEV-containing regimen was associated with monthly cost savings in the range of US\$550-US\$1180.

Stanisic et al estimated the indirect cost of adding BEV to regimens commonly used to treat metastatic NSCLC, such as cisplatin plus gemcitabine $(\mathrm{CG})$ or carboplatin and paclitaxel (CP). The authors hypothesized that the increasing duration in progression-free survival (PFS) for patients treated with BEV-containing regimens could transform into productivity gain (ie, reduction in indirect costs). ${ }^{14}$ 


\begin{tabular}{|c|c|c|c|}
\hline $\begin{array}{l}\text { Setting, dosing, } \\
\text { and intervention }\end{array}$ & Results $^{\mathbf{a}}$ & Conclusion & Comment and sensitivity analyses \\
\hline $\begin{array}{l}\text { - First-line BEV: } 15 \mathrm{mg} / \mathrm{kg} \\
\text { - Comparators: } \mathrm{PC}, \mathrm{CG} \text {, } \\
\mathrm{CP} \text {, and BCP } \\
\text { - } \mathrm{PC} \text { versus } \mathrm{CG} \text { obtained } \\
\text { from a head-to-head } \\
\text { trial - (PC versus } \mathrm{CP} \text { ) or } \\
\text { (PC versus } \mathrm{BCP}) \text { from } \\
\text { indirect comparisons }\end{array}$ & $\begin{array}{l}\text { For nonsquamous } \\
\text { NSCLC (USD; LY): } \\
\text { BCP: } \$ 95,952 ; 1.04 \\
\text { PC: } \$ 69,816 ; 0.97 \\
\text { CG: } \$ 65,01 \text { I; } 0.9 \\
\text { CP: } \$ 56,355 ; 0.89 \\
\text { BCP versus PC } \\
\text { ICER: } \$ 359,302 \text { per/LY; } \\
\text { ICUR: } \$ 1,072,076 / \text { QALY }\end{array}$ & $\begin{array}{l}\text { PC may be considered } \\
\text { cost-effective when } \\
\text { compared with commonly } \\
\text { used regimens for first-line } \\
\text { chemotherapy for } \\
\text { advanced NSCLC, } \\
\text { particularly in } \\
\text { nonsquamous NSCLC }\end{array}$ & $\begin{array}{l}\text { - Primary objective: CEA for PC versus } \\
\text { other first-line regimens (including BCP) } \\
\text { - Costs: premedication, chemotherapy, } \\
\text { laboratory, adverse events, subsequent } \\
\text { therapies, direct care for disease-related } \\
\text { morbidity, and end-of-life care } \\
\text { - If BEV dose } 7.5 \mathrm{mg} / \mathrm{kg} \text {, ICER of BCP } \\
\text { to PC reduced to } \$ 136,8 \mid 4 / \mathrm{LY}\end{array}$ \\
\hline $\begin{array}{l}\text { - First-line BEV: } 7.5 \mathrm{mg} / \mathrm{kg} \\
\text { - BCG versus PC obtained } \\
\text { from indirect comparison } \\
\text { (through CG) }\end{array}$ & $\begin{array}{l}\text { - } \text { BCG: } \$ 23,309 ; \text { I. } 5 \text { I LY } \\
\text { PC: } \$ 18,576 ; \text { I.39 LY } \\
\text { - ICER (BCG versus PC): } \\
\$ 4 I, 250 / L Y\end{array}$ & $\begin{array}{l}\text { BEV-based therapy is } \\
\text { cost-effective compared } \\
\text { with PEM-based therapy in } \\
\text { the treatment of advanced } \\
\text { nonsquamous NSCLC }\end{array}$ & $\begin{array}{l}\text { Costs: administration, supportive care, } \\
\text { and adverse events } \\
\text { - One-way sensitivity showed the change } \\
\text { in ICER ranged from }-14 \% \text { to }+15 \%\end{array}$ \\
\hline $\begin{array}{l}\text { - First-line } B E V \text { : } 15 \mathrm{mg} / \mathrm{kg} \\
\text { - } B C P \text { versus } C P \text { obtained } \\
\text { from a pivotal trial }\end{array}$ & $\begin{array}{l}\text { BCP: } \$ 1 \text { I9,438; I.24 LY, } \\
0.66 \text { QALY } \\
\text { CP: } \$ 45,638 ; \text { I.0I LY, } \\
\text { 0.53 QALY } \\
\text { - ICER: } \$ 318,386 / L Y \\
\text { ICUR: } \$ 576,64 \text { I/QALY }\end{array}$ & $\begin{array}{l}\text { BEV does not appear } \\
\text { to be cost-effective when } \\
\text { added to chemotherapy } \\
\text { in patients with } \\
\text { advanced NSCLC }\end{array}$ & $\begin{array}{l}\text { - Cost: drugs, treatment and office visits } \\
\text { for serious side effects, cost of PD } \\
\text { - If BEV dose } 7.5 \mathrm{mg} / \mathrm{kg} \text {, ICER reduced } \\
\text { to } \$ 163,839 / \mathrm{LY} \\
\text { - One-way sensitivity analysis showed } \\
\text { that findings were sensitive to survival } \\
\text { in the stable disease in BEV group, } \\
\text { number of BEV cycles, and utility } \\
\text { of the stable disease state } \\
\text { - Probabilistic sensitivity analysis: } \\
\text { the probability that BEV was } \\
\text { cost-effective was }<0.2 \% \text { at threshold } \\
\text { of } \$ 100,000 / Q A L Y\end{array}$ \\
\hline $\begin{array}{l}\text { - First-line BEV: } 7.5 \mathrm{mg} / \mathrm{kg} \\
\text { - BCG versus PC obtained } \\
\text { from indirect comparison } \\
\text { (through CG) }\end{array}$ & $\begin{array}{l}\text { - BCG versus PC } \\
\text { Korea: }(\$ 62,013 ; 3.59 \text { LY) } \\
\text { (\$28,69I; } 2.49 \text { LY) } \\
\text { Taiwan: }(\$ 145,819 ; 3.76 \text { LY) } \\
\text { (\$84,278; } 2.57 \text { LY) } \\
\text { ICER: } \$ 30,3 \text { I } 8 / \text { LY Korea } \\
\text { \$54,3 I } 7 / \text { LY Taiwan }\end{array}$ & $\begin{array}{l}\text { BCG is cost-effective } \\
\text { when compared with } \\
\text { PC for patients with } \\
\text { advanced NSCLC in } \\
\text { Korea and Taiwan }\end{array}$ & $\begin{array}{l}\text { - Costs: drug acquisition, administration, } \\
\text { supportive care costs, and managing AE } \\
\text { - One-way sensitivity analysis showed no } \\
\text { noticeable impact on ICER } \\
\text { - Cost-effectiveness acceptability curve: } \\
\text { the probability that BEV was cost-effective } \\
\text { at } \$ 100,000 / L Y \text { was } 100 \%\end{array}$ \\
\hline $\begin{array}{l}\text { - Maintenance therapy, } \\
\text { BEV: } 15 \mathrm{mg} / \mathrm{kg} \\
\text { - Comparators: PEM, } \\
\text { BEV, BSC, and Er } \\
\text { - PEM versus BEV and } \\
\text { PEM versus Er obtained } \\
\text { from indirect comparison }\end{array}$ & $\begin{array}{l}\text { - Cost; LY } \\
\text { BEV: } \$ \text { I I2,9 I3; I.29 LY } \\
\text { PEM: } \$ 103,124 ; 1.34 \mathrm{LY} \\
\text { Er: } \$ 77,044 ; 1.12 \mathrm{LY} \\
\text { BSC: } \$ 69,084 ; 1.08 \mathrm{LY} \\
\text { - BEV was dominated } \\
\text { by PEM }\end{array}$ & $\begin{array}{l}\text { PEM may be considered } \\
\text { cost-effective when } \\
\text { compared with other } \\
\text { agents for maintenance } \\
\text { therapy in advanced NSCLC, } \\
\text { particularly in patients with } \\
\text { nonsquamous cell histology }\end{array}$ & $\begin{array}{l}\text { - Primary objective: CEA for PEM versus } \\
\text { other maintenance therapy (including BEV) } \\
\text { - Costs: chemotherapy, laboratory, } \\
\text { AE, subsequent therapies, direct care } \\
\text { for disease-related morbidity, } \\
\text { and end-of-life care } \\
\text { - The comparison with BEV was not } \\
\text { considered in sensitivity analyses }\end{array}$ \\
\hline
\end{tabular}

Notes: aDollars in 20II USD; beither some authors were employees of a company contracted with the pharmacy company that produce drug PEM or sponsored by the pharmacy company that produces drug PEM; 'sponsored by the pharmacy company that produces drug BEV; 'by currency conversion rate.

Abbreviations: AE, adverse event; ASP, average sales price; BCG, BEV + cisplatin + gemcitabine (CG); BCP, BEV + carboplatin + paclitaxol (CP); BSA, body surface area; BSC, best supportive care; BW, bodyweight; CEA, cost-effectiveness analysis; Er, erlotinib; ICER, incremental cost-effectiveness ratio; ICUR, incremental cost-utility ratio; LY, life year; NSCLC, non-small cell lung cancer; PC, premetrexed/cisplatin; PD, progressive disease; PEM, pemetrexed; PS, performance status; QALY, quality adjusted LY; RCT, randomized controlled trial; USD, US dollars.

The authors then applied the human capital approach to estimate indirect costs by combining the above clinical benefit with labor market data and concluded that adding BEV to standard chemotherapy regimens for metastatic NSCLC was associated with productivity gain in the range between US\$16,700 and US\$26,000 at year 1 and between US\$30,000 and US\$46,900 at year 1.5 among patients who were in the labor market prior to their cancer diagnosis and were able to return to work after completing their treatment. 


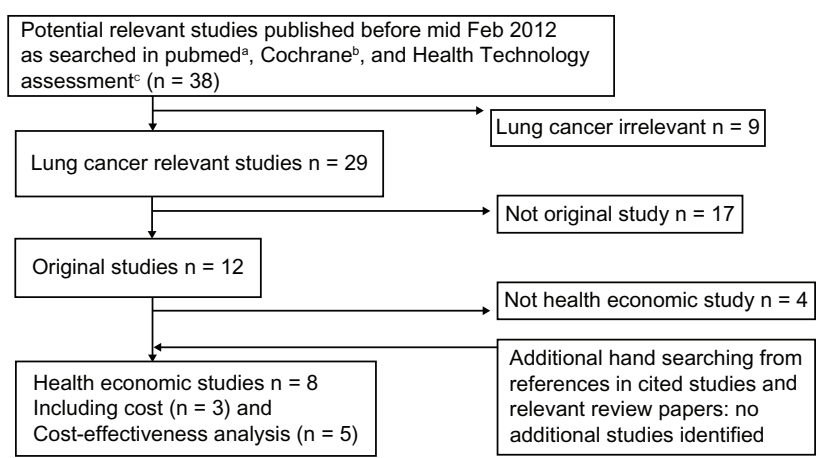

Figure I Flowchart of literature searching.

Notes: ahttp://www.ncbi.nih.gov/sites/entrez?db=pubmed; 'bttp://www.thecochrane library.com/view/0/index/html; chttp://www.hta.ac.uk/searchmonos.html.

\section{CEA/CUA}

Table 2 describes the five CEA/CUA studies that included $\mathrm{BEV}$ in the treatment of NSCLC. ${ }^{15-19}$ Four studies considered $\mathrm{BEV}$-containing chemotherapy regimen as first-line treatment for patients with advanced NSCLC, especially those with non-squamous histology; another study explored BEV as maintenance therapy for advanced NSCLC after patients had completed first-line double platinum chemotherapy without experiencing disease progression. All five studies were modeling studies employing either Markov or semiMarkov models.

Four of the five studies included the comparison of BEVcontaining regimens and PEM-containing, as both $\mathrm{BEV}$ and PEM are newly available therapies for NSCLC. Because, to date, there is no head-to-head trial comparing regimens, including these two new agents, indirect comparison was performed in these four studies. As in the review of the above cost studies, conflicting findings were observed in this present review of the CEA/CUA studies. Using BEV dose of $15 \mathrm{mg} / \mathrm{kg}$ as the base of comparison, Klein and colleagues reported that $\mathrm{BEV}$ alone or in combination with other chemotherapy agents is no more cost-effective than PEM, either as first-line treatment or maintenance therapy. ${ }^{15,19} \mathrm{On}$ the contrary, Guiliani et $\mathrm{al}^{16}$ and $\mathrm{Ahn}$ et $\mathrm{al}^{18}$ both concluded that BCG (using BEV $7.5 \mathrm{mg} / \mathrm{kg}$ ) is cost-effective when compared with PC. The study by Goulart and Ramsey explored the cost-effectiveness of adding BEV to more conventional third-generation chemotherapy (CP) using data from a pivotal Eastern Cooperative Oncology Group (ECOG) clinical trial and concluded that BCP (using BEV $15 \mathrm{mg} / \mathrm{kg}$ ) was not cost effective compared with $\mathrm{CP} .{ }^{17}$

\section{Discussion}

In this review of economic evaluation of $\mathrm{BEV}$ in the treatment of NSCLC, inconsistent findings were found on the cost saving or cost effectiveness of BEV-containing regimens across studies. The authors' attempts to reconcile the differences across studies were hindered by numerous factors, such as the dose of BEV administered, variations in treatment pattern by countries, comparators of choice, elements included in the calculation of costs, type of costs (direct and/ or indirect costs) reported, and the study timeframe.

A noticeable difference in the two cost studies that report opposite findings regarding whether BEV is cost saving is the dosage of BEV, with a lower dose $(7.5 \mathrm{mg} / \mathrm{kg})$ observed in the study that concludes lower costs of $\mathrm{BEV}$-containing regimens than PEM-containing regimens. ${ }^{13}$ The same observation applied to the cost-effectiveness analyses as well. In the two studies where the dosage of BEV was included in sensitivity analyses, ${ }^{15,17}$ the incremental cost-effectiveness ratio (ICER) associated with BEV administrated at $7.5 \mathrm{mg} / \mathrm{kg}$ was approximately half of that estimated based on BEV dosed at $15 \mathrm{mg} /$ $\mathrm{kg}$ (US\$163,839 versus US\$318,386 per life year in Goulart and Ramsey ${ }^{17}$ and US\$136,814 versus US\$359,302 per life year in Klein et $\mathrm{al}^{15}$ ). While it is not surprising that a lower dosage of BEV would be associated with more favorable economic benefit of BEV-containing regimens, it should be noted that the dosage of BEV in the initial clinical trial which led to the FDA approval was $15 \mathrm{mg} / \mathrm{kg}$. The ECOG 4599 trial demonstrated that patients treated with BEV $15 \mathrm{mg} / \mathrm{kg}$ in combination with CP had significantly higher PFS and overall survival than those treated with $\mathrm{CP}{ }^{6}$

In a subsequent trial known as the AVAiL trial, the investigators compared $\mathrm{BEV}$ at 7.5 or $15 \mathrm{mg} / \mathrm{kg}$ in combination with CG alone. ${ }^{20,21}$ The trial showed improved PFS (hazard ratio $0.82, P=0.03$ ) in the comparison of low-dose $\mathrm{BEV}$ plus $\mathrm{CG}$ versus $\mathrm{CG}$ alone, but no statistically significant difference in survival between low-dose and high-dose (15 mg/kg) BEV-containing regimens. ${ }^{20,21}$ However, the investigators cautioned that although the treatment effect of $\mathrm{BEV}$ at either dose relative to placebo appeared to be similar, the trial was not powered to directly compare these two doses of BEV. Although BEV dosed at $7.5 \mathrm{mg} / \mathrm{kg}$ is considered off-label use, as the dosage differs from that approved by the FDA, the low-dose BEV is not against the current National Comprehensive Cancer Network guideline for NSCLC, in which the guideline states that "bevacizumab + chemotherapy or chemotherapy alone is indicated in performance status $0-1$ patients with advanced or recurrent NSCLC." 22 Future trials with adequate power to compare the efficacy of BEV administered at high versus low dose will solidify cost-effectiveness based upon low-dose BEV had the trial demonstrated equal efficacy between these two 
doses. This is important because this current review reveals that the choice of BEV dose was highly correlated with the sponsorship, with lower dose used in studies sponsored by the company manufacturing BEV and higher dose in those sponsored by the company manufacturing PEM.

None of the economic studies employed a societal perspective, despite recommendations from various textbooks or good practice guidelines of economic evaluations. ${ }^{23,24}$ Theoretically, one could proximate estimates from societal perspective by combining the estimates of indirect costs by Stanisic et $\mathrm{al}^{14}$ with estimates of direct medical costs. However, researchers interested in applying this approach need to exercise extreme caution and not use the estimates of indirect cost reported in that study without making further adjustment. The estimated US\$16,700-US\$26,000 cost savings associated with $\mathrm{BEV}$-containing regimen was the mean cost for the group of patients who were under age 55 and eligible to return to work, a highly selected subgroup. That is, these estimates do not represent the average cost savings, but only reflect conditional means. This present study's re-calculation using the clinical and labor market information provided in that paper suggested that the average cost-saving would be in the range of US\$240-US\$420.

This present study contributes to the literature of economic evaluation of new treatments for NSCLC by reviewing cost or cost-effectiveness studies involving BEV. In a recently published systematic review for cost-effectiveness of new agents for advanced NSCLC, the authors concluded that in first-line treatment, $C G$ was cost-effective when compared with other conventional regimens, and that $\mathrm{PC}$ was cost-effective when compared with $\mathrm{CG}$ for nonsquamous advanced NSCLC. ${ }^{4}$ The same study also reported that erlotinib was the most cost-effective regimen for second-line treatment of NSCLC. The role of BEV was not discussed in that review.

This present review identified several gaps in the current literature. First, the role of BEV in other settings (such as adjuvant or second-line) and thus its economic values remained unknown. Second, in the era of personalized medicine, the role of BEV-containing regimen for specific genetic disposition (such as those with epidermal growth factor receptor [EGFR] mutation) remained unclear when $\mathrm{BEV}$-containing regimen was compared with EGFR inhibitors in this population. The cost-effectiveness of BEV could vary drastically if a predictive biomarker for BEV becomes available in the future. Lastly, there is currently no comprehensive economic evaluation (ie, include both direct and indirect costs) of BEV for NSCLC, and information available from the literature cannot be directly applied to generate estimates from the societal perspective.

\section{Conclusion}

In this review of economic evaluation of $\mathrm{BEV}$ in the treatment of NSCLC, it was found that the literature is inconclusive on the cost and cost-effectiveness of BEV, especially when the comparison involves PEM, another new agent for the treatment of NSCLC. With the exception of the study by Goulart and Ramsey ${ }^{17}$ commercial interests of the study sponsor appeared to play a role in the other studies. The role of BEV in other treatment settings for NSCLC was unknown. Further studies, such as clinical trials with adequate power to compare the efficacy between low-dose and high-dose $\mathrm{BEV}$, potential impact of predictive biomarkers for $\mathrm{BEV}$, and comprehensive economic evaluation, will strengthen the current state of knowledge on the economic value of BEV in NSCLC.

\section{Acknowledgments}

This study was partly supported by a grant from the National Science Council, Taiwan (NSC 98-2314-B-039-014-MY3) (C-R Chien), a grant from the Department of Health, Taiwan (DOH102-TD-C-111005) (C-R Chien), and funding from an NCI Challenge Grant (RC1CA145799), Agency for Healthcare Research and Quality (R01 HS018535), and The University of Chicago Cancer Research Foundation Women's Board (YCT Shih).

\section{Disclosure}

The authors report no conflicts of interest in this work.

\section{References}

1. Sullivan R, Peppercorn J, Sikora K, et al. Delivering affordable cancer care in high-income countries. Lancet Oncol. 2011;12(10): 933-980.

2. Chouaid C, Atsou K, Hejblum G, Vergnenegre A. Economics of treatments for non-small cell lung cancer. Pharmacoeconomics. 2009;27(2):113-125.

3. Vergnenègre A, Ray JA, Chouaid C, et al. Cross-market cost-effectiveness analysis of erlotinib as first-line maintenance treatment for patients with stable non-small cell lung cancer. Clinicoecon Outcomes Res. 2012;4:31-37.

4. Bongers ML, Coupé VM, Jansma EP, Smit EF, Uyl-de Groot CA. Cost effectiveness of treatment with new agents in advanced nonsmall-cell lung cancer: a systematic review. Pharmacoeconomics. 2012;30(1):17-34.

5. Herbst RS, Bajorin DF, Bleiberg H, et al. Clinical cancer advances 2005: major research advances in cancer treatment, prevention, and screeninga report from the American Society of Clinical Oncology. J Clin Oncol. 2006;24(1):190-205.

6. Sandler A, Gray R, Perry MC, et al. Paclitaxel-carboplatin alone or with bevacizumab for non-small-cell lung cancer. $N$ Engl $J$ Med. 2006;355(24):2542-2550. 
7. http://www.accessdata.fda.gov/scripts/cder/drugsatfda/index.cfm. Silver Spring: US Food and Drug Administration; Bevacizumab [revised May 2012; cited: May 12, 2012]. Available from: http://www.accessdata.fda. gov/drugsatfda_docs/label/2012/125085s02381bl.pdf. Accessed May 27, 2012.

8. Schrag D. The price tag on progress - chemotherapy for colorectal cancer. N Engl J Med. 2004;351(4):317-319.

9. Shih YC, Elting LS, Pavluck AL, Stewart A, Halpern MT. Immunotherapy in the initial treatment of newly diagnosed cancer patients: utilization trend and cost projections for non-Hodgkin's lymphoma, metastatic breast cancer, and metastatic colorectal cancer. Cancer Invest. 2010;28(1):46-53.

10. Bureau of Labor Statistics. Washington: US Bureau of Labor Statistics; Consumer Price Index (All Urban Consumers, item: medical care) [cited May 18, 2012]. Available from: http://data.bls.gov/timeseries/ CUUR0000SAM. Accessed May 27, 2012.

11. International Monetary Fund. World Economic Outlook Database [cited May 18, 2012]. Available from: http://www.imf.org/external/pubs/ft/ weo/2009/02/weodata/index.aspx. Accessed May 27, 2012.

12. Isla D, González-Rojas N, Nieves D, Brosa M, Finnern HW. Treatment patterns, use of resources, and costs of advanced non-small-cell lung cancer patients in Spain: results from a Delphi panel. Clin Transl Oncol. 2011;13(7):460-471.

13. Bischoff HG, Heigener DF, Walzer S, Nuijten M. Costs of bevacizumab and pemetrexed for advanced non-squamous NSCLC in Italy and Germany. Lung Cancer. 2010;69 Suppl 1:S18-S23.

14. Stanisic S, Bischoff HG, Heigener DF, et al. Societal cost savings through bevacizumab-based treatment in non-small cell lung cancer (NSCLC). Lung Cancer. 2010;69 Supp1 1:S24-S30.

15. Klein R, Muehlenbein C, Liepa AM, Babineaux S, Wielage R, Schwartzberg L. Cost-effectiveness of pemetrexed plus cisplatin as first-line therapy for advanced nonsquamous non-small cell lung cancer. J Thorac Oncol. 2009;4(11):1404-1414.
16. Giuliani G, Grossi F, de Marinis F, Walzer S. Cost-effectiveness analysis of bevacizumab versus pemetrexed for advanced non-squamous NSCLC in Italy. Lung Cancer. 2010;69 Suppl 1:S11-S17.

17. Goulart B, Ramsey S. A trial-based assessment of the cost-utility of bevacizumab and chemotherapy versus chemotherapy alone for advanced non-small cell lung cancer. Value Health. 2011;14(6):836-845.

18. Ahn MJ, Tsai CM, Hsia TC, et al. Cost-effectiveness of bevacizumabbased therapy versus cisplatin plus pemetrexed for the first-line treatment of advanced non-squamous NSCLC in Korea and Taiwan. Asia Pac J Clin Oncol. 2011;7 Suppl 2:S22-S33.

19. Klein R, Wielage R, Muehlenbein C, et al. Cost-effectiveness of pemetrexed as first-line maintenance therapy for advanced nonsquamous non-small cell lung cancer. J Thorac Oncol. 2010;5(8):1263-1272.

20. Reck M, von Pawel J, Zatloukal P, et al. Phase III trial of cisplatin plus gemcitabine with either placebo or bevacizumab as first-line therapy for nonsquamous non-small-cell lung cancer: AVAil. J Clin Oncol. 2009;27(8):1227-1234.

21. Reck M, von Pawel J, Zatloukal P, et al. Overall survival with cisplatingemcitabine and bevacizumab or placebo as first-line therapy for nonsquamous non-small-cell lung cancer: results from a randomised phase III trial (AVAiL). Ann Oncol. 2010;21(9):1804-1809.

22. http://www.nccn.org/index.asp. Fort Washington: National Comprehensive Cancer Network. NCCN clinical practice guidelines in oncology. Non-small cell lung cancer v2.2012 [cited December 17, 2011]. Available from: http://www.nccn.org/professionals/physician_gls/pdf/ nscl.pdf (free registration required). Accessed December 17, 2011.

23. Weinstein MC, O’Brien B, Hornberger J, et al. Principles of good practice for decision analytic modeling in health-care evaluation: report of the ISPOR Task Force on Good Research Practices - Modeling Studies. Value Health. 2003;6(1):9-17.

24. Drummond MF, Sculpher MJ, Torrance GW, O’Brien BJ, Stoddart GL. Methods for the Economic Evaluation of Health Care Programmes. 3rd ed. New York: Oxford University Press; 2005.
ClinicoEconomics and Outcomes Research

\section{Publish your work in this journal}

ClinicoEconomics \& Outcomes Research is an international, peerreviewed open-access journal focusing on Health Technology Assessment, Pharmacoeconomics and Outcomes Research in the areas of diagnosis, medical devices, and clinical, surgical and pharmacological intervention. The economic impact of health policy and health systems

\section{Dovepress}

organization also constitute important areas of coverage. The manuscript management system is completely online and includes a very quick and fair peer-review system, which is all easy to use. Visit http://www.dovepress.com/testimonials.php to read real quotes from published authors. 